\title{
Hospice Care Experiences Among Cancer Patients and Their Caregivers
}

\author{
Layla Parast, $\mathrm{PhD}^{7}$ (1), Anagha A. Tolpadi, MS ${ }^{7}$, Joan M. Teno, MD, MS², \\ Marc N. Elliott, $P h D^{\prime}$, and Rebecca Anhang Price, $P h D^{3}$ \\ 'RAND Corporation, Santa Monica, CA, USA; ${ }^{2}$ Oregon Health \& Science University, Portland, OR, USA; ${ }^{3}$ RAND Corporation, Arlington, VA, USA.
}

BACKGROUND: Little is known about the current quality of care for hospice cancer patients and how it varies across hospice programs in the USA.

OBJECTIVE: To examine hospice care experiences among decedents with a primary cancer diagnosis and their family caregivers, comparing quality across settings of hospice care.

DESIGN: We analyzed data from the Consumer Assessment of Healthcare Providers and Systems Hospice Survey (32\% response rate). Top-box outcomes (0-100) were calculated overall and by care setting, adjusting for survey mode and patient case mix.

PARTICIPANTS: Two hundred seventeen thousand five hundred ninety-six caregiver respondents whose family member had a primary cancer diagnosis and died in 2017 or 2018 while receiving hospice care from 2,890 hospices nationwide.

MAIN MEASURES: Outcomes (0-100 scale) included 8 National Quality Forum-endorsed quality measures, as well as responses to 4 survey questions assessing whether needs were met for specific symptoms (pain, dyspnea, constipation, anxiety/sadness).

KEY RESULTS: Quality measure scores ranged from 74.9 (Getting Hospice Care Training measure) to 89.5 (Treating Family Member with Respect measure). The overall score for Getting Help for Symptoms was 75.1 with item scores within this measure ranging from 60.6 (getting needed help for feelings of anxiety or sadness) to 84.5 (getting needed help for pain). Measure scores varied significantly across settings and differences were large in magnitude, with caregivers of decedents who received care in a nursing home $(\mathrm{NH})$ or assisted living facility (ALF) setting consistently reporting poorer quality of care. CONCLUSIONS: Important opportunities exist to improve hospice care for symptom palliation and providing training for caregivers when their family members are at home or in an ALF setting. Efforts to improve care for cancer patients in the $\mathrm{NH}$ and ALF setting are especially needed.

KEY WORDS: hospice care; cancer; patient experience; pain.

Supplementary Information The online version contains supplementa ry material available at https://doi.org/10.1007/s11606-020-06490-x.

Received April 17, 2020

Accepted December 17, 2020

Published online January 19, 2021
J Gen Intern Med 36(4):961-9

DOI: $10.1007 / \mathrm{s} 11606-020-06490-\mathrm{x}$

(C) Society of General Internal Medicine 2021

\section{INTRODUCTION}

About half $(50.4 \%)$ of Medicare beneficiaries who died in 2017 used hospice. ${ }^{1}$ Cancer is the leading principal diagnosis of hospice patients; in 2017, 30.1\% of Medicare decedents who received hospice care had a terminal diagnosis of cancer. ${ }^{2}$ In the USA, hospice care originated and was specifically intended for those with terminal cancer, and for many years, hospice care was largely only provided to patients with cancer. ${ }^{3-7}$ However, a change to the Medicare hospice benefit in 1986 extended hospice care to beneficiaries living in nursing homes, including many beneficiaries with non-cancer diagnoses, and resulted in a dramatic increase in the number of hospice organizations and the number of patients receiving hospice care. ${ }^{1,3,8}$ In addition, extension of hospice care to those living in nursing homes led to a change in the settings of care in which hospice patients tend to reside (with many more hospice patients in a nursing home setting) and a significant shift in the patient population, with cancer patients becoming less than half of patients receiving hospice care. ${ }^{9-13}$

Previous work examining the quality of hospice care for cancer patients ${ }^{12,14-18}$ has generally found their quality of care to be better than or comparable to that received by those with other diagnoses such as dementia and end-stage chronic disease. ${ }^{19,20}$ However, little is known about the current quality of care for hospice cancer patients and how it varies across hospice programs in the USA. The goals of hospice care, which is considered the model for high-quality compassionate care for those with a terminal illness, are to provide "expert medical care, pain management, and emotional and spiritual support expressly tailored to the patient's needs and wishes," as well as provide support to the patient's family. ${ }^{2,21,22}$ Quality of care in the hospice setting, therefore, is measured by assessing to what extent these goals were met. ${ }^{23}$ Understanding the current quality of care is particularly important in light of recent and continued changes in the hospice market, changes to the population of patients receiving hospice care, and increased national attention towards improving end of life care. 
In 2012, the Centers for Medicare \& Medicaid Services (CMS) introduced the Hospice Quality Reporting Program (HQRP) to measure and compare the quality of care provided by hospices. As a result of the HQRP, since 2015, hospices nationwide have been required to collect data on patient and family experiences of hospice care using the Consumer Assessment of Healthcare Providers and Systems (CAHPS®) Hospice Survey in order to avoid a financial penalty. ${ }^{23,24}$ Information obtained from this survey is used to calculate validated National Quality Forum (NQF)-endorsed quality measure scores across several domains of care, providing a unique opportunity to rigorously examine and compare hospice care quality. ${ }^{25-27}$ In this paper, we used 2017-2018 national CAHPS Hospice Survey data to examine multiple quality of care measures reflecting experiences with hospice care among decedents who had a primary diagnosis of cancer and their family caregivers, and investigate differences in quality across various settings of care and across hospice programs.

\section{METHODS}

\section{Study Sample}

Since 2015, all Medicare-certified hospices have been required to participate in the CAHPS Hospice Survey unless they are new or served fewer than 50 survey-eligible decedents/caregivers in the prior calendar year. The CAHPS Hospice Survey sample includes adult decedents who died at least $48 \mathrm{~h}$ after their last admission to hospice and for whom there is a caregiver of record with a US home address who is not a non-familial legal guardian. The national response rate for this survey is $32 \%$. Our analyses used CAHPS Hospice Survey data from 217,596 caregiver respondents whose family members died in 2017 or 2018 while receiving hospice care from any of 2,890 hospices nationwide; hospices located in Puerto Rico and hospices with fewer than 30 respondents were excluded, and survey responses where the primary diagnosis of the decedent was unknown or was not a type of cancer were excluded from all analyses.

\section{Survey Instrument and Administration Procedures}

The CAHPS Hospice Survey is completed by the primary informal caregiver of the hospice decedent (i.e., the family member or friend most knowledgeable regarding the hospice care received by the decedent). Surveys were administered to caregivers beginning 2 to 3 months after the patient's death and administered using one of three survey mode (mail only, telephone only, or mail with telephone follow-up). ${ }^{26,28}$ The CAHPS Hospice Survey has 47 questions, including questions about the decedent, the caregiver, hospice care the decedent received, hospice care received in a nursing home (if any), and the caregiver's experience with hospice. The development of the survey and its psychometric properties are described elsewhere. ${ }^{29}$

\section{Quality of Care Measures}

Responses to survey questions were used to calculate eight hospice quality measures: six composite measure scores (Hospice Team Communication, Getting Timely Care, Treating Family Member with Respect, Providing Emotional Support, Getting Help for Symptoms, Getting Hospice Care Training) and two global measures (Overall Rating of Hospice and Recommend Hospice). Table 1 lists the questions that compose each of these measures and response options for each question.

We also specifically examined each evaluative question within the Getting Help for Symptoms composite measure. These questions assess how often decedents received the help they needed with (1) pain, (2) trouble breathing, (3) constipation, and (4) feelings of anxiety or sadness, if they experienced those symptoms.

Per CAHPS Hospice Survey protocol, for each evaluative survey question within a measure, scores were calculated as the percentage of caregivers that endorsed the most positive response option(s) ("top-box" scoring; see Table 1). For example, for questions with response options "Never," "Sometimes," "Usually," "Always," where "Always" indicates better quality, the score would be the percentage of caregivers answering "Always"; detailed information on scoring is available elsewhere. ${ }^{30}$ In this paper, the person-level score for a composite measure composed of multiple questions was calculated by taking the average of the non-missing centered scores of each individual question.

\section{Decedent and Caregiver Characteristics}

This paper focused on the experiences of decedents/caregivers for whom the hospice indicated that the decedent's primary diagnosis was cancer. We included all types of cancers, identified using ICD-9/ICD-10 codes.

The decedent's setting of care was determined from the CAHPS Hospice Survey, which asked the caregiver respondent to indicate all settings in which the patient received hospice care. We classified these responses into mutually exclusive categories, as follows: home only, nursing home $(\mathrm{NH})$ only, acute care hospital $(\mathrm{ACH})$ only, freestanding hospice inpatient unit (IPU) only, assisted living facility (ALF) only, and more than one setting (multi-setting) or other setting. We focused on comparing home only, NH only, ACH only, IPU only, and ALF only settings ("only" dropped throughout for clarity); results related to the multi-/other/unknown setting were not described due to the heterogeneity of these groups.

Other available decedent and caregiver characteristics obtained from hospice administrative records included decedent age, decedent gender, payer for hospice care, and length of final episode of hospice care. In addition, 
Table 1 Quality of Care Measures

\begin{tabular}{|c|c|c|}
\hline Hospice Team Communication & Response Options & $\begin{array}{l}\text { Top Box } \\
\text { Response } \\
\text { Option }\end{array}$ \\
\hline $\begin{array}{l}\text { While your family member was in hospice care, how } \\
\text { often did the hospice team keep you informed about } \\
\text { when they would arrive to care for your family } \\
\text { member? }\end{array}$ & Never/Sometimes/Usually/Always & Always \\
\hline $\begin{array}{l}\text { While your family member was in hospice care, how } \\
\text { often did the hospice team explain things in a way that } \\
\text { was easy to understand? }\end{array}$ & Never/Sometimes/Usually/Always & Always \\
\hline $\begin{array}{l}\text { How often did the hospice team listen carefully to you } \\
\text { when you talked with them about problems with your } \\
\text { family member's hospice care? }\end{array}$ & Never/Sometimes/Usually/Always & Always \\
\hline $\begin{array}{l}\text { While your family member was in hospice care, how } \\
\text { often did the hospice team keep you informed about } \\
\text { your family member's condition? }\end{array}$ & Never/Sometimes/Usually/Always & Always \\
\hline $\begin{array}{l}\text { While your family member was in hospice care, how } \\
\text { often did the hospice team listen carefully to you? }\end{array}$ & Never/Sometimes/Usually/Always & Always \\
\hline $\begin{array}{l}\text { While your family member was in hospice care, how } \\
\text { often did anyone from the hospice team give you } \\
\text { confusing or contradictory information about your } \\
\text { family member's condition or care? }\end{array}$ & Never/Sometimes/Usually/Always & Never \\
\hline \multicolumn{3}{|l|}{ Getting Timely Care } \\
\hline $\begin{array}{l}\text { While your family member was in hospice care, when } \\
\text { you or your family member asked for help from the } \\
\text { hospice team, how often did you get help as soon as } \\
\text { you needed it? }\end{array}$ & Never/Sometimes/Usually/Always & Always \\
\hline $\begin{array}{l}\text { How often did you get the help you needed from the } \\
\text { hospice team during evenings, weekends, or holidays? }\end{array}$ & Never/Sometimes/Usually/Always & Always \\
\hline \multicolumn{3}{|l|}{ Treating Family Member with Respect } \\
\hline $\begin{array}{l}\text { While your family member was in hospice care, how } \\
\text { often did the hospice team treat your family member } \\
\text { with dignity and respect? }\end{array}$ & Never/Sometimes/Usually/Always & Always \\
\hline $\begin{array}{l}\text { While your family member was in hospice care, how } \\
\text { often did you feel that the hospice team really cared } \\
\text { about your family member? }\end{array}$ & Never/Sometimes/Usually/Always & Always \\
\hline \multicolumn{3}{|l|}{ Getting Emotional and Religious Support $^{\mathrm{a}}$} \\
\hline $\begin{array}{l}\text { While your family member was in hospice care, how } \\
\text { much emotional support did you get from the hospice } \\
\text { team? }\end{array}$ & $\begin{array}{l}\text { Too Little/Right Amount/Too } \\
\text { Much }^{1}\end{array}$ & $\begin{array}{l}\text { Right } \\
\text { Amount }\end{array}$ \\
\hline $\begin{array}{l}\text { In the weeks after your family member died, how } \\
\text { much emotional support did you get from the hospice } \\
\text { team? }\end{array}$ & $\begin{array}{l}\text { Too Little/Right Amount/Too } \\
\text { Much }^{1}\end{array}$ & $\begin{array}{l}\text { Right } \\
\text { Amount }\end{array}$ \\
\hline $\begin{array}{l}\text { Support for religious or spiritual beliefs includes } \\
\text { talking, praying, quiet time, or other ways of meeting } \\
\text { your religious or spiritual needs. While your family } \\
\text { member was in hospice care, how much support for } \\
\text { your religious and spiritual beliefs did you get from the } \\
\text { hospice team? }\end{array}$ & $\begin{array}{l}\text { Too Little/Right Amount/Too } \\
\text { Much }^{1}\end{array}$ & $\begin{array}{l}\text { Right } \\
\text { Amount }\end{array}$ \\
\hline \multicolumn{3}{|l|}{ Getting Help for Symptoms } \\
\hline $\begin{array}{l}\text { Did your family member get as much help with pain as } \\
\text { he or she needed? }\end{array}$ & Never/Sometimes/Usually/Always & Always \\
\hline
\end{tabular}


Table 1 Continued

\begin{tabular}{|l|l|l|}
\hline $\begin{array}{l}\text { How often did your family member get the help he or } \\
\text { she needed for trouble breathing? }\end{array}$ & Never/Sometimes/Usually/Always & Always \\
\hline $\begin{array}{l}\text { How often did your family member get the help he or } \\
\text { she needed for trouble with constipation? }\end{array}$ & Never/Sometimes/Usually/Always & Always \\
\hline $\begin{array}{l}\text { How often did your family member receive the help he } \\
\text { or she needed from the hospice team for feelings of } \\
\text { anxiety or sadness? }\end{array}$ & Never/Sometimes/Usually/Always & Always \\
\hline Getting Hospice Care Training & & \\
\hline $\begin{array}{l}\text { Did the hospice team give you enough training about } \\
\text { what side effects to watch for from pain medicine? }\end{array}$ & Yes Definitely/Yes Somewhat/No & $\begin{array}{l}\text { Yes } \\
\text { Definitely }\end{array}$ \\
\hline $\begin{array}{l}\text { Did the hospice team give you the training you needed } \\
\text { about if and when to give more pain medicine to your } \\
\text { family member? }\end{array}$ & Yes Definitely/Yes Somewhat/No & Yes \\
\hline $\begin{array}{l}\text { Did the hospice team give you the training you needed } \\
\text { about how to help your family member if he or she had } \\
\text { trouble breathing? }\end{array}$ & Yes Definitely/Yes Somewhat/No & $\begin{array}{l}\text { Yes } \\
\text { Definitely }\end{array}$ \\
\hline $\begin{array}{l}\text { Did the hospice team give you the training you needed } \\
\text { about what to do if your family member became } \\
\text { restless or agitated? }\end{array}$ & Yes Definitely/Yes Somewhat/No & $\begin{array}{l}\text { Yes } \\
\text { Definitely }\end{array}$ \\
\hline $\begin{array}{l}\text { Side effects of pain medicine include things like } \\
\text { sleepiness. Did any member of the hospice team } \\
\text { discuss side effects of pain medicine with you or your } \\
\text { family member? }\end{array}$ & Yes Definitely/Yes Somewhat/No & $\begin{array}{l}\text { Yes } \\
\text { Definitely }\end{array}$ \\
\hline Global Measures & & \\
\hline $\begin{array}{l}\text { Using any number from 0 to 10, where 0 is the worst } \\
\text { hospice care possible and 10 is the best hospice care } \\
\text { possible, what number would you use to rate your } \\
\text { family member's hospice care? }\end{array}$ & 0/1/2/3/4/5/6/7/8/9/10 & 9 or 10 \\
\hline $\begin{array}{l}\text { Would you recommend this hospice to your friends } \\
\text { and family? }\end{array}$ & $\begin{array}{l}\text { Definitely No/Probably } \\
\text { No/Probably Yes/Definitely Yes }\end{array}$ & Yes \\
\hline $\begin{array}{l}\text { Responses of Too Much were not included in scoring per current CAHPS Hospice Survey scoring } \\
\text { b Only calculated among those who received care in the home or ALF setting }\end{array}$ \\
\hline
\end{tabular}

decedent and caregiver characteristics obtained from the survey were caregiver age, caregiver education, relationship of caregiver to decedent, language spoken at home, decedent race/ethnicity, caregiver involvement in care, symptom prevalence, and need for care. Caregiver involvement in care was obtained from the survey using the question "While your family member was in hospice care, how often did you take part in or oversee care for him or her?" with response options Never, Sometimes, Usually, Always. Caregivers responding that they never oversaw care did not respond to evaluative items and were not included in the analytic dataset. Symptom prevalence and need for care were obtained from the survey (e.g., "While your family member was in hospice care, did he or she have any pain?") with response options Yes or No. Only caregivers responding Yes to these questions were asked subsequent questions regarding care the decedent received for these needs (see Table 1).

\section{Statistical Analysis}

All analyses of measures and evaluative questions were adjusted for mode of survey administration ${ }^{26}$; in addition, all analyses were weighted to account for sample design and nonresponse at the hospice level. We first examined the characteristics of decedents with a primary diagnosis of cancer, overall and stratified by setting of care. Second, we examined overall quality of hospice care for decedents with a primary diagnosis of cancer by calculating the mean score for each measure. Third, we examined measure scores by setting and tested for differences between settings by fitting a weighted regression model with the measure score as the outcome and setting of care as the main predictor, with home as the reference group. Though we included the multi-setting/other/unknown group when calculating overall scores, we excluded this group in the regression model and all significance tests were performed with this group omitted. Following CAHPS Hospice Survey protocol, all regression models were adjusted 
for differences in case mix using the following variables: decedent age, payer for hospice care, and length of final episode of hospice care; respondent age, education, relationship to decedent, language spoken at home, and survey language; and response percentile (reflecting the length of time between decedent death and survey response). ${ }^{27}$ To determine the extent to which results were driven by between-hospice differences (i.e., due to the concentration of cancer decedents in particular hospices), as a sensitivity analysis, we examined all regression models additionally adjusting for hospice fixed effects and compared these results to our main results. Lastly, to assess variability in care quality across hospices, we calculated and examined the distribution of case mix and modeadjusted hospice-level scores among cancer decedents only; for analytic stability, only hospices with 30 or more cancer decedent/caregiver respondents were included in this analysis (1,667 hospices). This study was approved by the Institutional Review Board at the RAND Corporation.

\section{RESULTS}

The majority of decedents with cancer were white, had Medicare as their sole payer for hospice care, had a caregiver who was a spouse or partner, and received hospice care at home
(Table 2). There was significant variation in these characteristics by setting of care; for example, the NH and ALF settings had a higher percentage of white decedents and $\mathrm{NH}, \mathrm{ACH}$, and IPU settings had more decedents with Medicaid only or Medicaid and private insurance as a payer for hospice care.

The most prevalent symptom was pain, which was reported by over $80 \%$ of caregivers of cancer decedents (Table 2). Over $60 \%$ of caregivers reported that their family member had feelings of anxiety or sadness, $49.9 \%$ reported that their family member had trouble breathing, and $49.4 \%$ reported that their family member had trouble with constipation. Reported symptom prevalence varied significantly by setting with higher prevalence for all symptoms in the home setting compared to all other settings.

With respect to need for care, nearly $75 \%$ of caregivers reported needing to contact the hospice team during evenings, weekends, or holidays for questions or help with their family member's care, and $43 \%$ reported talking with the hospice team about problems with their family member's hospice care (Table 2).

Quality measure scores among cancer decedents ranged from 74.9 (Getting Hospice Care Training measure) to 89.5 (Treating Family Member with Respect measure), as shown in Table 3. The overall score for Getting Help for Symptoms was 75.1 with item scores within this measure ranging from 60.6

Table 2 Characteristics of Hospice Patients with a Primary Diagnosis of Cancer and Their Caregivers

\begin{tabular}{|c|c|c|c|c|c|c|}
\hline & $\begin{array}{c}\text { Overall, } \\
\text { Mean (SD) or \% }\end{array}$ & $\begin{array}{c}\text { Home, } \\
\text { Mean (SD) or \% }\end{array}$ & $\begin{array}{l}\text { Nursing Home, } \\
\text { Mean (SD) or } \%\end{array}$ & $\begin{array}{c}\text { Acute Care } \\
\text { Hospital, } \\
\text { Mean (SD) or \% }\end{array}$ & $\begin{array}{c}\text { Freestanding } \\
\text { Hospice IPU, } \\
\text { Mean (SD) or \% }\end{array}$ & $\begin{array}{l}\text { Assisted Living } \\
\text { Facility, } \\
\text { Mean (SD) or } \%\end{array}$ \\
\hline Total N & 217,596 & 134,936 & 12,306 & 6,138 & 20,632 & 8,017 \\
\hline Age at death (years) $* * *$ & $75.3(12.0)$ & $74.8(11.7)$ & $80.3(11.4)$ & $72.9(11.9)$ & $73.3(12.1)$ & $85.5(9.6)$ \\
\hline Female $* * *$ & $46.5 \%$ & $44.3 \%$ & $54.1 \%$ & $47.7 \%$ & $47.9 \%$ & $59.3 \%$ \\
\hline \multicolumn{7}{|l|}{ Race/ethnicity *** } \\
\hline White & $86.4 \%$ & $85.7 \%$ & $87.4 \%$ & $82.9 \%$ & $85.9 \%$ & $93.3 \%$ \\
\hline Black & $5.8 \%$ & $5.8 \%$ & $7.3 \%$ & $8.7 \%$ & $7.0 \%$ & $2.5 \%$ \\
\hline Hispanic & $4.7 \%$ & $5.2 \%$ & $3.2 \%$ & $5.6 \%$ & $4.4 \%$ & $2.6 \%$ \\
\hline Other & $3.0 \%$ & $3.3 \%$ & $2.2 \%$ & $2.8 \%$ & $2.7 \%$ & $1.6 \%$ \\
\hline \multicolumn{7}{|l|}{ Length of final stay (days) $* * *$} \\
\hline 2-5 days & $19.1 \%$ & $15.8 \%$ & $17.6 \%$ & $63.1 \%$ & $43.5 \%$ & $11.1 \%$ \\
\hline 6-12 days & $20.3 \%$ & $20.1 \%$ & $19.2 \%$ & $26.5 \%$ & $30.1 \%$ & $15.5 \%$ \\
\hline 13-29 days & $22.6 \%$ & $24.4 \%$ & $21.2 \%$ & $7.2 \%$ & $16.0 \%$ & $20.8 \%$ \\
\hline 30-80 days & $22.3 \%$ & $24.1 \%$ & $22.5 \%$ & $2.3 \%$ & $7.5 \%$ & $24.0 \%$ \\
\hline $81+$ days & $15.7 \%$ & $15.7 \%$ & $19.6 \%$ & $0.9 \%$ & $3.0 \%$ & $28.5 \%$ \\
\hline \multicolumn{7}{|l|}{ Payer for Hospice Care $* * *$} \\
\hline Medicare only & $67.0 \%$ & $69.2 \%$ & $59.1 \%$ & $63.5 \%$ & $57.9 \%$ & $80.5 \%$ \\
\hline $\begin{array}{l}\text { Medicaid only or Medicaid and } \\
\text { Private Insurance }\end{array}$ & $2.9 \%$ & $2.5 \%$ & $4.2 \%$ & $4.7 \%$ & $4.1 \%$ & $0.7 \%$ \\
\hline Medicare and Medicaid & $2.7 \%$ & $1.4 \%$ & $16.4 \%$ & $2.2 \%$ & $3.0 \%$ & $3.3 \%$ \\
\hline Private insurance only & $8.7 \%$ & $9.4 \%$ & $2.5 \%$ & $10.7 \%$ & $10.5 \%$ & $1.6 \%$ \\
\hline Private insurance and Medicare & $6.0 \%$ & $5.9 \%$ & $3.6 \%$ & $6.5 \%$ & $7.8 \%$ & $4.9 \%$ \\
\hline Other & $12.6 \%$ & $11.6 \%$ & $14.2 \%$ & $12.4 \%$ & $16.6 \%$ & $9.0 \%$ \\
\hline \multicolumn{7}{|l|}{ Involvement in Care $* * *$} \\
\hline Sometimes & $7.8 \%$ & $5.0 \%$ & $15.6 \%$ & $12.2 \%$ & $13.6 \%$ & $16.6 \%$ \\
\hline Usually & $14.2 \%$ & $11.9 \%$ & $20.6 \%$ & $14.5 \%$ & $17.2 \%$ & $23.9 \%$ \\
\hline Always & $78.0 \%$ & $83.2 \%$ & $63.8 \%$ & $73.3 \%$ & $69.2 \%$ & $59.6 \%$ \\
\hline Caregiver Relationship (Decedent & & & & & & \\
\hline
\end{tabular}


Table 2 Continued

\begin{tabular}{|c|c|c|c|c|c|c|}
\hline \multicolumn{7}{|l|}{ was the caregiver's ___ $* * *$} \\
\hline Spouse or partner & $54.5 \%$ & $61.1 \%$ & $22.3 \%$ & $55.1 \%$ & $51.4 \%$ & $14.6 \%$ \\
\hline Parent & $29.4 \%$ & $26.2 \%$ & $47.0 \%$ & $25.6 \%$ & $27.9 \%$ & $64.7 \%$ \\
\hline Mother-in-law or father-in-law & $1.5 \%$ & $1.5 \%$ & $2.0 \%$ & $0.8 \%$ & $1.2 \%$ & $3.0 \%$ \\
\hline Aunt or uncle & $1.4 \%$ & $0.9 \%$ & $4.6 \%$ & $1.5 \%$ & $1.5 \%$ & $4.2 \%$ \\
\hline Sister or brother & $6.2 \%$ & $4.5 \%$ & $13.5 \%$ & $9.3 \%$ & $9.6 \%$ & $6.4 \%$ \\
\hline Child & $2.5 \%$ & $2.3 \%$ & $2.2 \%$ & $3.6 \%$ & $3.4 \%$ & $1.1 \%$ \\
\hline Friend & $2.0 \%$ & $1.5 \%$ & $3.5 \%$ & $1.8 \%$ & $2.4 \%$ & $2.9 \%$ \\
\hline Other & $2.5 \%$ & $2.0 \%$ & $4.8 \%$ & $2.4 \%$ & $2.7 \%$ & $3.2 \%$ \\
\hline \multicolumn{7}{|l|}{$\begin{array}{l}\text { Symptom Prevalence While } \\
\text { Receiving Hospice Care }\end{array}$} \\
\hline Patient had pain $* * *$ & $80.1 \%$ & $82.1 \%$ & $76.9 \%$ & $66.4 \%$ & $70.6 \%$ & $77.8 \%$ \\
\hline P** & $49.9 \%$ & $52.1 \%$ & $47.6 \%$ & $43.7 \%$ & $40.2 \%$ & $47.2 \%$ \\
\hline $\begin{array}{l}\text { Patient had trouble with } \\
\text { constipation } * * *\end{array}$ & $49.4 \%$ & $54.5 \%$ & $35.0 \%$ & $21.9 \%$ & $25.0 \%$ & $38.8 \%$ \\
\hline $\begin{array}{l}\text { Patient showed feelings of } \\
\text { anxiety or sadness } * * *\end{array}$ & $60.6 \%$ & $62.0 \%$ & $59.1 \%$ & $41.9 \%$ & $45.5 \%$ & $59.0 \%$ \\
\hline \multicolumn{7}{|l|}{ Need for Care } \\
\hline $\begin{array}{l}\text { Caregiver reported needing to } \\
\text { contact the hospice team during } \\
\text { evenings, weekends, or holidays for } \\
\text { questions or help with family } \\
\text { member's care } * * *\end{array}$ & $74.9 \%$ & $83.4 \%$ & $46.3 \%$ & $35.4 \%$ & $47.5 \%$ & $63.1 \%$ \\
\hline $\begin{array}{l}\text { Caregiver reported talking with } \\
\text { the hospice team about any } \\
\text { problems with family member's } \\
\text { hospice care } * * *\end{array}$ & $42.5 \%$ & $43.5 \%$ & $39.8 \%$ & $31.4 \%$ & $33.5 \%$ & $41.5 \%$ \\
\hline \multicolumn{7}{|c|}{$\begin{array}{l}\text { *** }<0.001 \\
\text { all means and percentages were calculated among non-missing values. There were } 2 \text { respondents with missing age, } 3,827 \text { with missing race, } 57 \text { with missing } \\
\text { length of final stay, } 9,753 \text { with missing payer for health care services, } 2,032 \text { with missing gender, } 3,354 \text { missing involvement in care, and } 2,033 \text { missing } \\
\text { relationship to caregiver. There were } 4,641,5,030,5,655 \text {, and } 5,954, \text { missing responses to items assessing whether the patient had pain, trouble breathing, } \\
\text { trouble with constipation, and feelings of anxiety or sadness, respectively, and there were } 7,666 \text { and } 6,819 \text { with missing responses to items assessing whether } \\
\text { the caregiver reported needing to contact the hospice team during evenings, weekends, or holidays for questions or help with family member's care and if they } \\
\text { reported talking with the hospice team about any problems with family member's hospice care, respectively. } \\
\text { 'Chi-squared tests were used for categorical variables and an analysis of variance was used for continuous variables to test across settings; tests were performec } \\
\text { among non-missing categories only and exclude cases with multiple reported settings of care and with an other or unknown setting of care. }\end{array}$} \\
\hline
\end{tabular}

(getting needed help for feelings of anxiety or sadness) to 84.5 (getting needed help for pain); symptom scores were only calculated among caregivers who reported that the family member experienced the relevant symptom.
Measure scores varied significantly across settings with the highest scores being in either the home setting or IPU setting (Table 3; see Appendix Table 1 for results with 95\% confidence intervals); differences between settings were large in

Table 3 Caregiver Reports of Care Experiences among Cancer Decedents and Their Caregivers

\begin{tabular}{|c|c|c|c|c|c|c|c|}
\hline & Overall & Home & $\begin{array}{l}\text { Nursing } \\
\text { Home }\end{array}$ & $\begin{array}{l}\text { Acute care } \\
\text { hospital }\end{array}$ & $\begin{array}{l}\text { Freestanding } \\
\text { hospice IPU }\end{array}$ & $\begin{array}{l}\text { Assisted living } \\
\text { facility }\end{array}$ & $p$ \\
\hline & Mean & Mean & Mean & Mean & Mean & Mean & \\
\hline Hospice team communication & 81.2 & 83.5 & 72.1 & 76.1 & 81.3 & 73.3 & $* * *$ \\
\hline Getting timely care & 78.0 & 79.0 & 70.7 & 76.1 & 82.7 & 71.7 & $* * *$ \\
\hline Treating family member with respect & 89.5 & 90.3 & 86.8 & 87.6 & 89.7 & 88.2 & $* * *$ \\
\hline Getting emotional support & 89.0 & 88.9 & 88.0 & 88.3 & 91.1 & 89.4 & $* * *$ \\
\hline Getting hospice care training & 74.9 & 77.4 & - & - & - & 56.6 & $* * *$ \\
\hline Overall rating of hospice & 80.1 & 80.5 & 72.6 & 78.3 & 86.3 & 75.2 & $* * *$ \\
\hline Willingness to recommend hospice & 84.6 & 84.9 & 77.3 & 80.8 & 90.1 & 79.8 & $* * *$ \\
\hline Getting help for symptoms & 75.1 & 76.5 & 66.1 & 74.1 & 79.5 & 68.6 & $* * *$ \\
\hline Got help with pain when needed & 84.5 & 85.7 & 76.1 & 86.2 & 89.8 & 78.7 & $* * *$ \\
\hline $\begin{array}{l}\text { Got help for trouble breathing when } \\
\text { needed }\end{array}$ & 81.7 & 83.1 & 73.5 & 78.4 & 83.4 & 75.5 & $* * *$ \\
\hline Got help for constipation when needed & 71.0 & 72.6 & 59.5 & 63.2 & 74.0 & 62.6 & $* * *$ \\
\hline $\begin{array}{l}\text { Got help for feelings of anxiety or } \\
\text { sadness when needed }\end{array}$ & 60.6 & 63.0 & 48.2 & 56.9 & 64.9 & 49.9 & $* * *$ \\
\hline
\end{tabular}

Means within each setting are adjusted for differences in decedent age, payer for hospice care, and length of final episode of hospice care, respondent age, education, relationship to caregiver, language spoke at home, and survey language, and response percentile (reflecting the lag time between patient death and survey response). All means are also adjusted for mode. Note: Getting hospice care training is not applicable to the nursing home, acute care hospital, or freestanding hospice IPU settings

$* * * p<0.001$ 


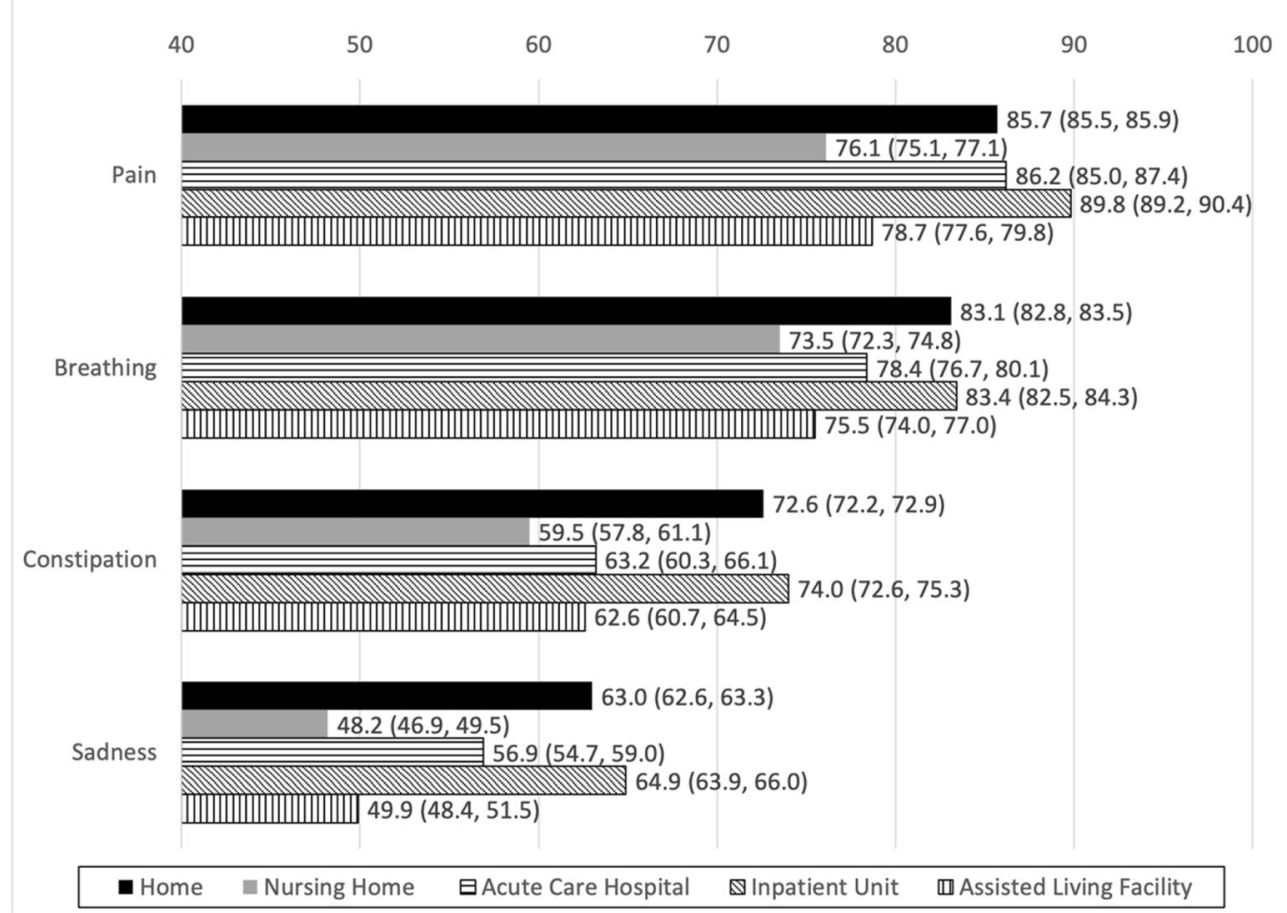

Figure 1 Getting help for symptoms, by setting. Notes: Getting help for symptoms scores (and corresponding $95 \%$ confidence intervals) are on a 0-100 scale and adjusted for mode and differences in decedent age, payer for hospice care, and length of final episode of hospice care, respondent age, education, relationship to caregiver, language spoke at home, and survey language, and response percentile (reflecting the lag time between patient death and survey response); scores are calculated only among decedents who experienced the given symptom, as reported by the caregiver.

magnitude. ${ }^{31}$ The nursing home and ALF settings had the lowest scores for most measures, with symptoms scores as low as $48.2(\mathrm{NH})$ and 49.9 (ALF) for the item assessing whether the patient got needed help for feelings of anxiety or sadness (Fig. 1). Results including hospice fixed effects (see Appendix Table 2) were similar, indicating that overall results are not driven by between-hospice differences.

The distributions of hospice-level scores (Table 4) showed wide variation across hospices for all measures. For example, while the average hospice-level score for the symptoms measure was 75.6, the 10th percentile of hospice scores was 68.1 and the 90th percentile was 83.3.

\section{DISCUSSION}

In this nationwide comprehensive study of the quality of care received by hospice patients with cancer, we found room for improvement in the quality of care that caregivers reported for cancer patients, particularly with respect to getting help for symptoms. Only 3 out of 5 caregivers reported that patients received help for feelings of anxiety or sadness when needed, while receiving hospice care. While there was some variation across setting - 48 to $65 \%$ of caregivers reported receiving help for such feelings across settings - symptom management for anxiety or sadness was the least frequently addressed symptom across the board, compared to other symptoms. Given the impact and risk of depression and suicidal ideation among hospice patients, effective efforts by hospice staff to address these symptoms are critical. ${ }^{32-35}$ Though reported experience was better for other symptoms, roughly 1 out of 6 patients did not always receive help with pain when needed, 1 out of 6 patients did not receive help for trouble breathing when needed, and more than a quarter of patients did not receive help for constipation when needed. Symptom management is an essential aspect of hospice care; high-quality care for symptom control is associated with a patient's quality of life at the end of life, as well as their quality of death. ${ }^{2,36-38}$ Efforts to improve symptom management in the hospice setting for cancer patients are needed.

Interestingly, though caregivers of those receiving hospice care at home were more likely to report that the decedent needed help for symptoms than caregivers in other settings, caregivers reported that their family member received help for these symptoms in the home setting as often or more often compared to other settings. That is, cancer patients who choose to and/or are able to receive hospice care at home may be more likely to experience symptoms, but when they do, they are more likely to get help for those symptoms than patients who receive hospice care in other settings. It is possible that because these patients are at home, their caregivers may be more aware when the patient experiences these symptoms and/or the patients may be better able to communicate these symptoms to their caregivers than in other settings.

In addition to symptom management, results showed substantial room for improvement in getting hospice care training, which 
Table 4 Distribution of Hospice-level Scores among Cancer Decedents and Their Caregivers

\begin{tabular}{|c|c|c|c|c|}
\hline & Mean & $\begin{array}{l}\text { 10th } \\
\text { percentile }\end{array}$ & $\begin{array}{l}\text { Median } \\
\text { (50th } \\
\text { percentile) }\end{array}$ & $\begin{array}{l}\text { 90th } \\
\text { percentile }\end{array}$ \\
\hline $\begin{array}{l}\text { Hospice team } \\
\text { communication }\end{array}$ & 82.0 & 75.1 & 82.4 & 88.4 \\
\hline $\begin{array}{l}\text { Getting timely } \\
\text { care }\end{array}$ & 78.8 & 69.8 & 79.5 & 87.4 \\
\hline $\begin{array}{l}\text { Treating family } \\
\text { member with } \\
\text { respect }\end{array}$ & 90.5 & 85.1 & 91.0 & 95.3 \\
\hline $\begin{array}{l}\text { Getting emotional } \\
\text { support }\end{array}$ & 89.7 & 85.0 & 90.0 & 93.8 \\
\hline $\begin{array}{l}\text { Getting hospice } \\
\text { care training }\end{array}$ & 76.7 & 68.7 & 76.7 & 84.5 \\
\hline $\begin{array}{l}\text { Overall rating of } \\
\text { hospice }\end{array}$ & 81.0 & 72.6 & 81.6 & 88.8 \\
\hline $\begin{array}{l}\text { Willingness to } \\
\text { recommend } \\
\text { hospice }\end{array}$ & 85.3 & 76.2 & 85.9 & 93.4 \\
\hline $\begin{array}{l}\text { Getting help for } \\
\text { symptoms }\end{array}$ & 75.6 & 68.1 & 75.7 & 83.3 \\
\hline $\begin{array}{l}\text { Got help with } \\
\text { pain when needed }\end{array}$ & 85.3 & 78.1 & 85.6 & 92.3 \\
\hline $\begin{array}{l}\text { Got help for } \\
\text { trouble breathing } \\
\text { when needed }\end{array}$ & 82.6 & 73.0 & 82.9 & 91.9 \\
\hline $\begin{array}{l}\text { Got help for } \\
\text { constipation when } \\
\text { needed }\end{array}$ & 72.1 & 60.4 & 72.3 & 83.4 \\
\hline $\begin{array}{l}\text { Got help for } \\
\text { feelings of } \\
\text { anxiety or } \\
\text { sadness when } \\
\text { needed }\end{array}$ & 62.3 & 50.2 & 61.8 & 75.2 \\
\hline
\end{tabular}

Hospice scores are calculated only among cancer decedents and their caregivers and are adjusted for mode and differences in decedent age, payer for hospice care, and length of final episode of hospice care, respondent age, education, relationship to caregiver, language spoke at home, and survey language, and response percentile (reflecting the lag time between patient death and survey response). Analysis is restricted to hospices with 30 or more cancer decedent/caregiver respondents (1,667 hospices)

only applies to the home and ALF settings (because this is specific to training of the family/friend caregiver, not staff), and is particularly poor in the ALF setting. One hypothesis is that the ALF setting may lack enough staff who can administer medicines. This difference in quality is not limited to getting hospice care training - differences in the reported quality of care for all measures across setting were dramatic, showing much poorer quality in the nursing home and ALF settings. Previous work examining differences in quality by setting of care have found similar patterns across a range of diagnoses. ${ }^{20,39-41}$ While the majority of cancer patients receiving hospice care receive such care at home, just under $40 \%$ in our sample received hospice care in a non-home setting. In addition, while an overwhelming majority of patients with advanced cancer prefer to die at home, ${ }^{39,42-44}$ they often die in an institutional setting. ${ }^{13,16,17,39,42,45-47}$ Efforts are needed to address observed lower quality care in certain hospice care settings in order to ensure that all patients receive high-quality care, regardless of setting.

These findings also highlight the importance of careful hospice choice when clinicians refer terminal cancer patients to hospice care. We find a wide range in quality across hospices - for all measures, there are hospices that perform well and those that perform poorly. The availability of publicly reported quality measure scores via the CMS HQRP now allows providers to understand the quality of care for hospices in a patient's geographic area and refer patients to higher-quality hospices when possible. While there are certainly many factors that inform a hospice referral decision, hospice care quality should be taken into consideration, particularly in light of highly variable, and sometimes poor, experiences for certain domains of care.

Our study has a number of limitations. First, we do not have information about multi-morbidity; our assessment of diagnosis is limited to the primary diagnosis at hospice enrollment. It is possible that our restriction to only the primary diagnosis is overly simplistic and that there may be unobserved confounding that could be accounted for if multi-morbidity information were available. ${ }^{13}$ Second, we do not have information regarding the number, timing, or type of transitions that patients may have undergone across care settings; such transitions are common and would likely reflect the complexity of patients' care needs. ${ }^{13,46}$ Lastly, our results may not generalize to all cancer patients receiving hospice care given that measure data are not available for small hospices and we can only calculate measure scores among those who respond to the survey. With respect to potential nonresponse bias, case mix adjusting for characteristics known to be associated with response likelihood and response patterns, as was done in this study, can mitigate such bias with less loss of precision than nonresponse weighting. ${ }^{48}$ Notably, strengths of our data included the nationwide representation and the ability to include patients with all types of cancer, with all insurances, and all adult ages.

The recent introduction of the CMS HQRP and requirement for the CAHPS Hospice Survey has provided the opportunity to investigate reported quality of care for cancer patients receiving hospice care as reported by their caregivers using validated quality measures in a large nationwide sample. These results demonstrate substantial need for improvement in symptom management and caregiver training for cancer patients in a home setting or ALF setting. Efforts to understand these discrepancies in quality of care by setting and to improve care for those in the $\mathrm{NH}$ and ALF setting are especially needed.

Corresponding Author: Layla Parast, PhD; RAND Corporation, Santa Monica, CA, USA (e-mail: parast@rand.org).

Funding The data collection and analysis on which this publication is based was sponsored under contract numbers HHSM-500-2016$00022 \mathrm{G}$ and 75FCMC19F0026, entitled, "National Implementation of the CAHPS Hospice Survey," funded by the Centers for Medicare and Medicaid Services, Department of Health and Human Services. The content of this publication neither necessarily reflect the views or policies of the Department of Health and Human Services nor does the mention of trade names, commercial products, or organizations imply endorsement by the US Government. The authors assume full responsibility for the accuracy and completeness of the ideas presented.

Prior presentations None. 


\section{REFERENCES}

1. MedPAC (Medicare Payment Advisory Commission). 2019. Report to the Congress: Medicare Payment Policy. Washington, DC: MedPAC.

2. NHPCO Facts and Figures: 2018 Edition. National Hospice and Palliative Care Organization. Alexandria, VA, July 2019.

3. Mor V, Teno JM. Regulating and paying for hospice and palliative care: reflections on the Medicare Hospice Benefit. Journal of health politics, policy and law 41:697-716, 2016

4. Higginson I. Palliative care: a review of past changes and future trends. Journal of Public Health 15:3-8, 1993

5. Clark D. Originating a movement: Cicely Saunders and the development of St Christopher's Hospice, 1957-1967. Mortality 3:43-63, 1998

6. Mor V, Birnbaum H. Medicare legislation for hospice care: implications of national hospice study data. Health Affairs 2:80-90, 1983

7. Mor V, Kidder D. Cost savings in hospice: final results of the National Hospice Study. Health Services Research 20:407, 1985

8. Bernstein A. Health care in America; trends in utilization. 2004

9. NHPCO 2005 National Summary of Hospice Care. National Hospice and Palliative Care Organization. Alexandria, VA, November 2006.

10. Gray B, Schlesinger M. Health//The State of Nonprofit America/Ed. by L. Salamon, Washington, DC: Brookings Institution Press, 2002

11. Bernstein A, Hing E, Moss A, et al. Health care in America, trends in utilization. US Department of Health and Human Services. Centers for disease control and prevention. National center for health statistics. Hyattsville, MD, 2003

12. Connor SR, Tecca M, LundPerson J, et al. Measuring hospice care: The national hospice and palliative care organization national hospice data set. Journal of pain and symptom management 28:316-328, 2004

13. Aldridge MD, Bradley EH. Epidemiology and patterns of care at the end of life: Rising complexity, shifts in care patterns and sites of death. Health Affairs 36:1175-1183, 2017

14. Wallston KA, Burger C, Smith RA, et al. Comparing the quality of death for hospice and non-hospice cancer patients. Medical care, 1988

15. Kane $\mathbf{R}$, Bernstein $\mathbf{L}$, Wales $\mathbf{J}$, et al. A randomised controlled trial of hospice care. The Lancet 323:890-894, 1984

16. Wright AA, Keating NL, Ayanian JZ, et al. Family perspectives on aggressive cancer care near the end of life. Jama 315:284-292, 2016

17. Kumar P, Wright AA, Hatfield LA, et al. Family perspectives on hospice care experiences of patients with cancer. Journal of clinical oncology $35: 432,2017$

18. Wallston KA, Burger C, Smith RA, et al. Comparing the quality of death for hospice and non-hospice cancer patients. Medical care 26:177-182, 1988

19. Mitchell SL, Kiely DK, Miller SC, et al. Hospice care for patients with dementia. Journal of pain and symptom management 34:7-16, 2007

20. Wachterman MW, Pilver C, Smith D, et al. Quality of end-of-life care provided to patients with different serious illnesses. JAMA internal medicine 176:1095-1102, 2016

21. National Consensus Project for Quality Palliative Care. Clinical Practice Guidelines for Quality Palliative Care, 4th edition. Richmond, VA: National Coalition for Hospice and Palliative Care; 2018. https://www. nationalcoalitionhpc.org/ncp.

22. Stewart AL, Teno J, Patrick DL, et al. The concept of quality of life of dying persons in the context of health care. Journal of pain and symptom management 17:93-108, 1999

23. Anhang Price R, Quigley DD, Bradley MA, et al. Hospice Experience of Care Survey: Development and Field Test. Santa Monica, CA: RAND Corporation; 2014.

24. Centers for Medicaid \& Medicare Services. Hospice Quality Reporting Program (HQRP). Requirements for the Fiscal Year (FY) 2018 Reporting Year. https://www.cms.gov/Medicare/Quality-Initiatives-Patient-Assessment-Instruments/Hospice-Quality-Reporting/Downloads/HospiceQuality-Reporting-Program_FY-2018-Fact-Sheet-August-2017.pdf Accessed June 10, 2018.

25. Agency for Healthcare Quality and Research. CAHPS Hospice Survey. https://www.ahrq.gov/cahps/surveys-guidance/hospice/index.html. Accessed August 28, 2019.

26. Parast L, Elliott MN, Hambarsoomian K, et al. Effects of Survey Mode on Consumer Assessment of Healthcare Providers and Systems (CAHPS)
Hospice Survey Scores. Journal of the American Geriatrics Society 66:546-552, 2018

27. Parast L, Haas A, Tolpadi A, et al. Effects of Caregiver and Decedent Characteristics on CAHPS Hospice Survey Scores. Journal of pain and symptom management 56:519-529, 2018

28. CAHPS Hospice Survey Quality Assurance Guidelines. https://www. hospicecahpssurvey.org/en/quality-assurance-guidelines/. Accessed August 28, 2019.

29. Anhang Price R, Stucky B, Parast L, et al. Development of valid and reliable measures of patient and family experiences of hospice care for public reporting. Journal of palliative medicine 21:924-932, 2018

30. CAHPS Hospice Survey: Scoring and Analysis. http://www.hospicecahpssurvey.org/en/scoring-and-analysis/. Accessed November 5, 2019.

31. Quigley DD, Elliott MN, Setodji CM, et al. Quantifying Magnitude of Group-Level Differences in Patient Experiences with Health Care. Health Services Research 53:3027-3051, 2018

32. Irwin SA, Rao S, Bower $\mathbf{K}$, et al. Psychiatric issues in palliative care: recognition of depression in patients enrolled in hospice care. Journal of palliative medicine 11:158-163, 2008

33. Garrison CM, Overcash J, McMillan SC. Predictors of quality of life in elderly hospice patients with cancer. Journal of hospice and palliative nursing: JHPN: the official journal of the Hospice and Palliative Nurses Association 13:288, 2011

34. Breitbart W, Rosenfeld B, Pessin H, et al. Depression, hopelessness, and desire for hastened death in terminally ill patients with cancer. Jama 284:2907-2911, 2000

35. Block SD. Panel ACoPASoIME-o-LCC: Assessing and managing depression in the terminally ill patient. Focus 132:209-319, 2005

36. Choi JY, Chang YJ, Song HY, et al. Factors that affect quality of dying and death in terminal cancer patients on inpatient palliative care units: perspectives of bereaved family caregivers. Journal of pain and symptom management 45:735-745, 2013

37. Weitzner MA, Moody LN, McMillan SC. Symptom management issues in hospice care. American Journal of Hospice and Palliative Medicine® 14:190-195, 1997

38. Singer PA, Martin DK, Kelner M. Quality end-of-life care: patients' perspectives. Jama 281:163-168, 1999

39. Wright AA, Keating NL, Balboni TA, et al. Place of death: correlations with quality of life of patients with cancer and predictors of bereaved caregivers' mental health. Journal of Clinical Oncology 28:4457, 2010

40. Teno JM, Clarridge BR, Casey V, et al. Family perspectives on end-of-life care at the last place of care. Jama 291:88-93 2004

41. Teno JM, Plotzke M, Christian T, et al. Examining variation in hospice visits by professional staff in the last 2 days of life. JAMA internal medicine 176:364-370, 2016

42. Jeurkar N, Farrington S, Craig TR, et al. Which hospice patients with cancer are able to die in the setting of their choice? Results of a retrospective cohort study. Journal of Clinical Oncology 30:2783, 2012

43. Tang ST. When death is imminent: where terminally ill patients with cancer prefer to die and why. Cancer Nursing 26:245-251, 2003

44. Townsend J, Frank A, Fermont D, et al. Terminal cancer care and patients' preference for place of death: a prospective study. Bmj 301:415417, 1990

45. Teno JM, Gozalo P, Trivedi AN, et al. Site of death, place of care, and health care transitions among US Medicare beneficiaries, 2000-2015. JAMA 320:264-271, 2018

46. Wright AA, Hatfield LA, Earle CC, et al. End-of-life care for older patients with ovarian cancer is intensive despite high rates of hospice use. Journal of Clinical Oncology 32:3534, 2014

47. Paris J, Morrison RS. Evaluating the effects of inpatient palliative care consultations on subsequent hospice use and place of death in patients with advanced GI cancers. Journal of oncology practice 10:174-177, 2014

48. Elliott MN, Zaslavsky AM, Goldstein E, et al. Effects of survey mode, patient mix, and nonresponse on CAHPS ${ }^{\circledR}$ hospital survey scores. Health services research 44:501-518, 2009

Publisher's Note: Springer Nature remains neutral with regard to jurisdictional claims in published maps and institutional affiliations. 